\title{
WILLOWS AND REEDS FOR BIOREMEDIATION OF LANDFILL LEACHATE: REDOX POTENTIAL IN THE ROOT ZONE
}

\author{
Peter Randerson, \\ School of Biosciences, Cardiff University, Cardiff, CF10 3AX, UK \\ Laura Davies, \\ School of Biosciences, Cardiff University, Cardiff, CF10 3AX, UK \\ Antonio Albuquerque, \\ Department of Civil Engineering and Architecture, University of Beira \\ Interior, Edificio 2 das Engenharias, Calcada Fonte do Lameiro, 6201- \\ 001, Covilha, Portugal \\ Andrzej Bialowiec \\ University of Warmia and Mazury in Olsztyn, Department of \\ Environmental Biotechnology, ul. Sloneczna 45 G, 10-900 Olsztyn, Poland
}

\begin{abstract}
Constructed wetlands can be used for bioremediation of landfill leachate (LL) making it safe to discharge into the environment. Wetland plants (reed and willow), contribute to pollutant removal, particularly of organic and nitrogen loads. Root exudates stimulate microbial activity and elevate oxygen levels in the rhizosphere which promotes nitrification. This study investigated the effects of reed and willow on bioremediation of LL in comparison with an unplanted control by measuring redox potential levels in the rhizosphere of microcosm systems in a greenhouse.

Redox potential in the reed rhizosphere was consistently the highest, with the willow rhizosphere consistently the lowest. Redox potential fluctuated in the willow rhizosphere during daylight hours, with large decreases in the morning. Levels of $\mathrm{NH}_{4}{ }^{+}$ decreased dramatically in the first day of the experiment and remained at similar low levels in all tanks. Removal of ammonia took place in the control tank with peaks in $\mathrm{NO}_{2}{ }^{-}$and $\mathrm{NO}_{3}{ }^{-}$, but levels of $\mathrm{NO}_{3}{ }^{-}$remained high. Removal of ammonia was also observed in the reed tank with a peak in $\mathrm{NO}_{2}{ }^{-}$, but there was no peak in $\mathrm{NO}_{3}{ }^{-}$, as well as in the willow tank, but there were no peaks in $\mathrm{NO}_{2}{ }^{-}$or $\mathrm{NO}_{3}{ }^{-}$. Final levels of totalnitrogen, nitrate and chemical oxygen demand where considerably lower in the reed and willow tank than the unplanted control.
\end{abstract}

\section{KEYWORDS}

Landfill leachate, constructed wetland, redox potential, nitrogen removal

https://doi.org/10.15626/Eco-Tech.2010.093 


\section{INTRODUCTION}

Landfill leachate (LL) is one of the main problems associated with landfill sites. It is formed when rain water filters through a landfill becoming contaminated with pollutants [12]. The composition of LL varies from site to site, but is generally characterised by high levels of total nitrogen $(\mathrm{N})$ ammonia $\left(\mathrm{NH}_{4}{ }^{+}\right.$or $\mathrm{NH}_{3}$, depending on $\left.\mathrm{pH}\right)$, nitrate $\left(\mathrm{NO}_{3}{ }^{-}\right)$, chemical oxygen demand $(\mathrm{COD})$, sodium $(\mathrm{Na})$, chloride $(\mathrm{Cl})$ and low ratio of $\mathrm{BOD} / \mathrm{COD}$ [11]. The major environmental impacts of leachate discharge are on surface and ground water quality. Ammonia is the main cause of toxicity, but it can also cause oxygen depletion and changes in the fauna and flora in surface water bodies $[6,12]$. Heavy metal toxicity generally presents little problem with LL due to its high $\mathrm{pH}$ and the amount of dissolved organic carbon present making the metals insoluble and nontoxic [11].

Treatment constructed wetlands $(\mathrm{CW})$ can be used in the remediation of LL making it safe to discharge into the environment. Using wetlands as an in situ way to remediate contaminated water and sediments can be used in the long term and is inexpensive and efficient when compared to other treatment options $[6,16]$.

$\mathrm{CW}$ with reed $[24,25]$ as well with willow $[3,13]$ have been shown to be effective in leachate from landfill sites and are especially successful at removing high levels of nitrogen from solution. A review of the potential for the use of willow filter beds and Short Rotation Plantation to treat landfill leachate by [7] concluded that several studies showed success of willow filter beds in treating leachate and that the leachate treatment improved with the number of the willows.

The plant root-soil interface plays a significant role in the removal of pollutants, especially of $\mathrm{N}$ from constructed wetlands [14]. Oxygen released from roots creates local aerobic conditions in the otherwise anaerobic rhizosphere, which induces growth of aerobic both heterotrophic and autotrophic bacteria (nitrifiers) and the aerobic breakdown of organic material [5]. As well as plant species, the release of oxygen into the rhizosphere is related to some extent to photosynthesis, light intensity, stomatal aperture, and temperature [19]. The removal of ammonia through nitrification it is advantageous not only because it helps in the removal of $\mathrm{N}$ loads, but also because the end $\mathrm{N}$ specie $\left(\mathrm{NO}_{3}{ }^{-}\right)$is much less toxic and more bioavailable to plants than $\mathrm{NH}_{4}{ }^{+}$[11]. Plant uptake also plays an important role in the enhancement of $\mathrm{N}$ removal, especially in treatment wetlands containing fast-growing plants such as willows [13]. Organic compounds, such as sugars, alcohols and acids, that are in the LL or released by plants into the rhizosphere can help in nitrate removal by acting as a carbon source for denitrifying bacteria [5].

The majority of microbial processing that occurs in wetlands is attributed to biofilms made up of communities of algae, bacteria, protozoa and invertebrates. It has been shown that up to $90 \%$ of organic and inorganic $\mathrm{N}$ can be removed from LL by biofilms [21].

Considering the differences in the release of oxygen into the rhizosphere between plant species and the effect that this release has on the remediation of LL in treatment wetlands it is important to be able to asses the oxidising or reducing capabilities of the rhizosphere. One way of doing this is through measuring the redox potential (Eh) [18], as oxidised aerobic environments generally have high Eh, while low Eh is linked to reduced anaerobic environments [9]. The protective oxidised layer around roots in the rhizosphere can create a redox gradient of $\sim 500 \mathrm{mV}$ at the root surface to $\sim-250 \mathrm{mV} 1-20$ $\mathrm{mm}$ away from the root surface [22]. 
In this paper we focused on the influence of plants on LL treatment performance by oxygen and organic exudate release, and plants' control of the subsurface aerobic/anoxic/anaerobic conditions.

\section{METHODOLOGY}

\subsection{Experimental design}

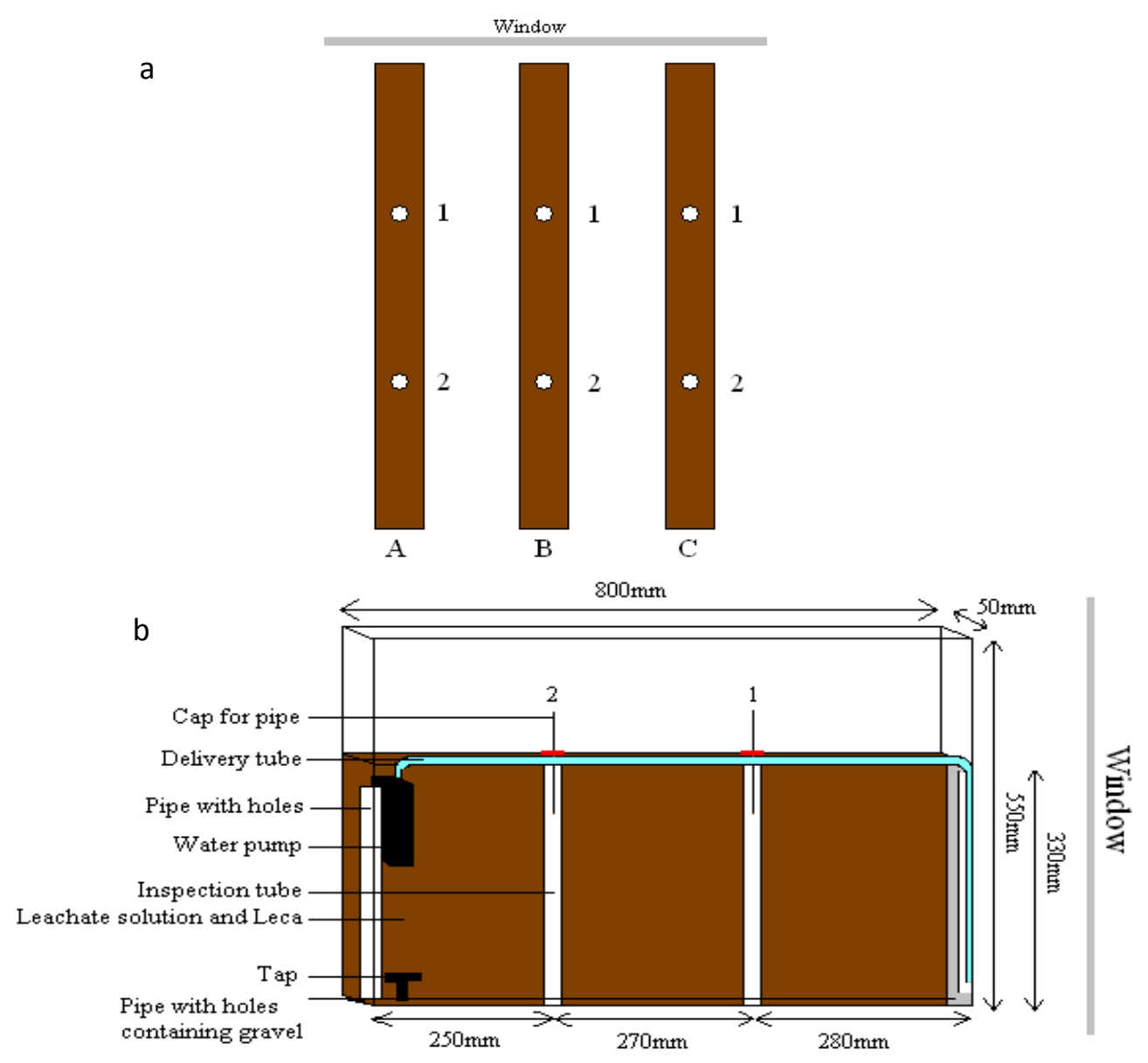

Figure 1. a - Tanks $A$ - reed, $B$ - willow and $C$ - control (left to right) in the greenhouse, (b) construction and dimensions of tanks, with LL recirculation system, and sampling tubes.

A greenhouse experiment was carried out to measure the effects of reeds and willow on the bioremediation of LL. Greenhouse temperatures were maintained above $14^{\circ} \mathrm{C}$ with the use of electric heating. LL from Lamby Way, Cardiff, non-hazardous landfill site (old section) was used in this study. Phytotoxicological tests, conducted according to [4], indicated the need for dilution of LL to $20 \%$ concentration to avoid direct toxic effects on plants.

Three glass tanks $(80 \times 5 \times 55 \mathrm{~cm}$; LxWxH) were used (Figure 1a, b). Tank A contained the common reed Phragmites australis (Cav.) Trin. ex Steud, tank B the willow Salix viminalis $x$ burjatica (var. Ashton Stott), and tank $\mathrm{C}$ was a control tank with no plants. 
The tanks were filled to a depth of $33 \mathrm{~cm}$ with LECA $0.5-2 \mathrm{~cm}$ in size with a layer of gravel placed over the top to prevent floating. To enable redox measurements and LL sampling each tank had two plastic inspection perforated tubes $(2 \mathrm{~cm}$ diameter $)$ inserted between the LECA. Water pumps (Mini Aqua One, 300F-LV, $150 \mathrm{~L} / \mathrm{h}, 2.5 \mathrm{~W}$ ) placed $2-3 \mathrm{~cm}$ below the surface of the LECA were used to circulate the LL solution in each tank.

Six sections of $P$. australis rhizome were planted in tank A (two on each side of the inspection tubes) and six pre-cultivated ( 5 weeks old) willow cuttings were planted in tank B (two on each side of the inspection tubes). Tanks were then filled to the height of the LECA with the $20 \%(\mathrm{v} / \mathrm{v})$ LL solution (A: $\left.5.5 \mathrm{dm}^{3}, \mathrm{~B}: 5.4 \mathrm{dm}^{3}, \mathrm{C} 5.2 \mathrm{dm}^{3}\right)$ and the sides of each tank were covered in aluminium foil to prevent algal growth by excluding light. After 36 days of initial plant growth and microbial colonisation in the system, LL was replaced by fresh diluted LL solution, and this system monitored for a period of 188 days. The tanks were subject to continuous recirculation as in a horizontal flow CW.

On the $67^{\text {th }}$ day of the experiment supplementary lighting between the hours of 05:00 and 21:00 was implemented to slow the senescence of the willow leaves.

\subsection{Sampling and measurements}

A multi-parameter analyser (Eijkelkamp 18.26) was used to take daily Eh measurements. Readings were taken from 20.07.2009 to 24.01.2010, and were started between 11:45 and 14:00 on week days and 07:00 and 09:00 on weekends. A thermometer attached to the wall of the greenhouse was used to record the ambient temperature of the greenhouse at the time the readings were started. Once the Eh readings were complete the water levels of each tank were checked. Tap water was used to maintain water levels to the height of the LECA.

LL samples were taken once a week for the first four weeks and on days 137 and 144. Three 20-25 ml samples of LL solution were taken from each tank, one from each inspection tube and one from the tap. A $60 \mathrm{ml}$ syringe and a piece of $5 \mathrm{~mm}$ tubing were used to collect samples from the inspection tubes. Samples from taps were poured directly into the sampling tube after it was rinsed. Samples of the $100 \%$ LL and $20 \%$ $(\mathrm{v} / \mathrm{v})$ LL solution were also taken on the first day of the experiment. The samples were analysed for levels of $\mathrm{NH}_{4}{ }^{+}$, Kjeldahl nitrogen, nitrite, nitrate, and COD using the standard International Organisation for Standardisation (ISO) methods (ISO 71501:1984, ISO 5664:1984, ISO 5663:1984, ISO 6777:1984, ISO 7890-3:1988 and ISO 6060:1989).

\section{RESULTS}

\subsection{Redox potential}

Eh in all tanks oscillated between days and over time (Figure 2). Tukey's test $(p<0.05)$ indicated that $\mathrm{Eh}$ in the reed tank was the least negative with a mean of $-102 \mathrm{mV}(\mathrm{SD}=$ $85 \mathrm{mV})$. The willow tank had the lowest Eh with a mean of $-286 \mathrm{mV}(\mathrm{SD}=118 \mathrm{mV})$, whilst in the control tank a mean of $-158 \mathrm{mV}(\mathrm{SD}=67 \mathrm{mV})$ was observed.

No relationship between redox and greenhouse temperature was found for any of the tanks over the whole sampling period.

For all the experiments the redox readings were more negative in the morning (8:00 to 10:00), increasing towards 11:00. The lowest value was observed for willow $(-500 \mathrm{mV})$. 
For the reed and control tanks the change in redox throughout the day were less marked and tended to stabilise after 11:00.

\subsection{Landfill leachate treatment}

The $20 \%(\mathrm{v} / \mathrm{v}) \mathrm{LL}$ used in the tanks was characterised by high levels of $\mathrm{NH}_{4}{ }^{+}$and COD (Fig. 3, 4). $\mathrm{NH}_{4}{ }^{+}$in all tanks and sampling points fell dramatically during the first day of operation and remained low till late in the experiment. This fall corresponded to a peak in the $\mathrm{NO}_{2}{ }^{-}$concentrations in the reed and control tanks (Figure 3). $\mathrm{NO}_{2}{ }^{-}$in the willow tank remained very low compared to the amounts in the reed and control tanks. The highest concentration of $\mathrm{NO}_{3}{ }^{-}$it was observed in the third week of sampling, particularly for the control tank, which had much higher levels of $\mathrm{NO}_{3}{ }^{-}$than the planted tanks. Furthermore, this peak in $\mathrm{NO}_{3}{ }^{-}$corresponded with a fall in the concentration of $\mathrm{NO}_{2}{ }^{-}$in the control tank (Figure 3). Levels of organic $\mathrm{N}$ in each tank varied over the sampling period, but were at about the same levels on days 137 and 144 as the $20 \%$ $(\mathrm{v} / \mathrm{v}) \mathrm{LL}$ at the start of the experiment. The amounts of TN fell over the sampling period. Levels of COD also fluctuated during the first four weeks, but generally showed a decline in levels (Figure 4).

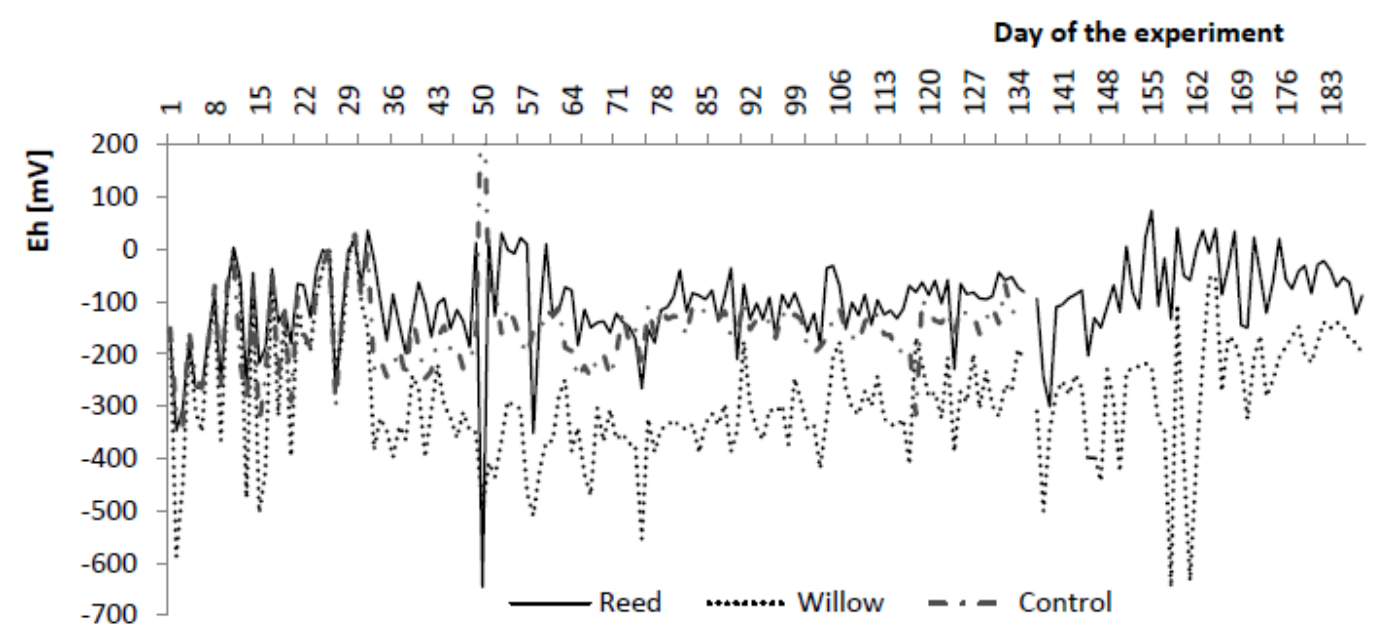

Figure 2. Redox changes over time in reed (A), willow (B) and control (C) tanks 

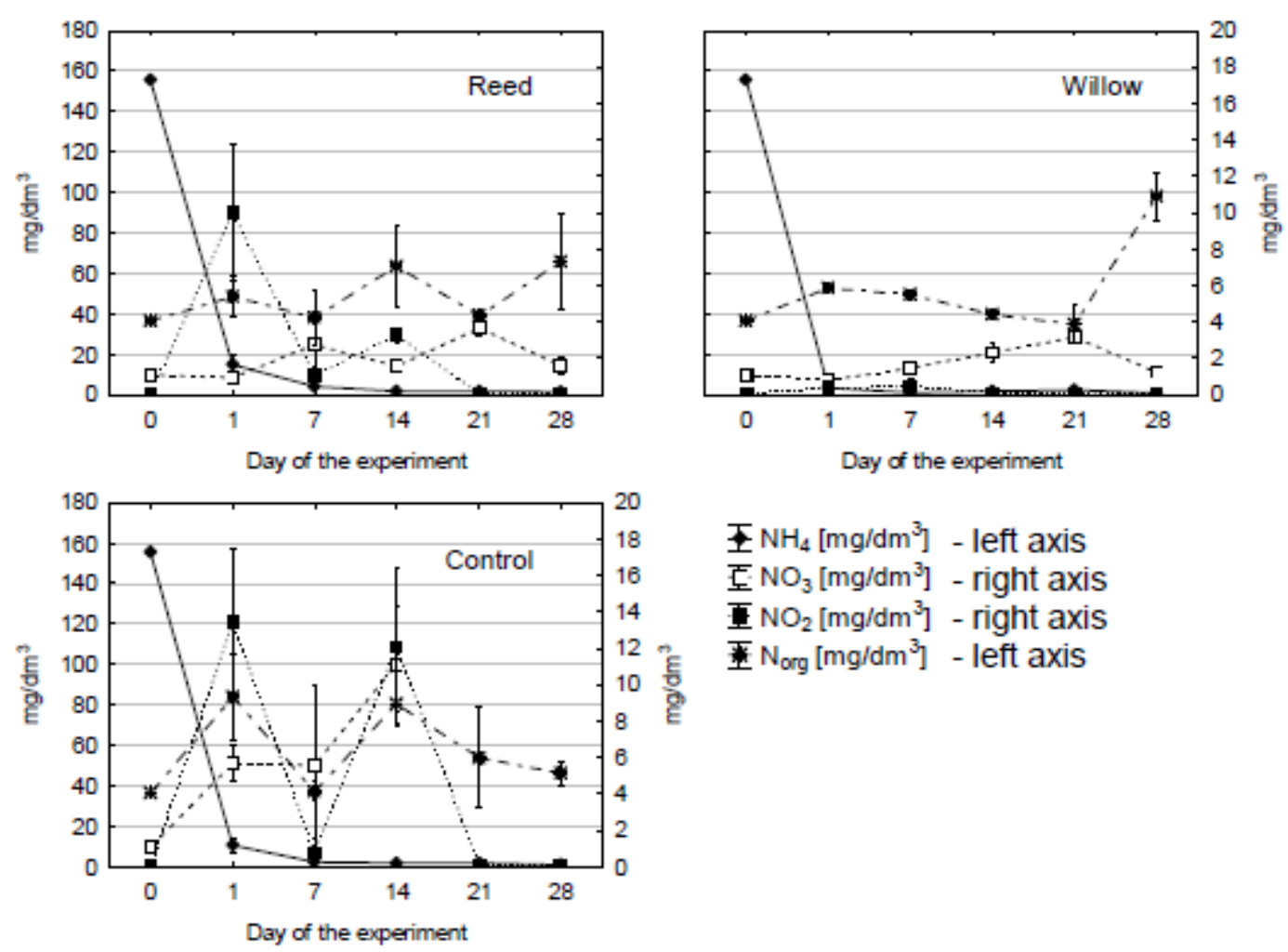

Figure 3. Changes in concentration of $\mathrm{N}-\mathrm{NH}_{4}, \mathrm{~N}-\mathrm{NO}_{2}, \mathrm{~N}-\mathrm{NO}_{3}$, organic- $\mathrm{N}$, in samples of LL(A-reed, B-willow, C-control)

\section{DISCUSSION}

\subsection{Redox potential and temperature}

Although, it has previously been found that there is a significant relationship between Eh and temperature, it is also known that the presence and species of plants can counteract the effects of temperature on Eh [2]. However, no relationship between Eh and temperature was found in the unplanted control tank suggesting that other factors were affecting the Eh, such as microbial activity and evapotranspiration/evaporation [8]. 

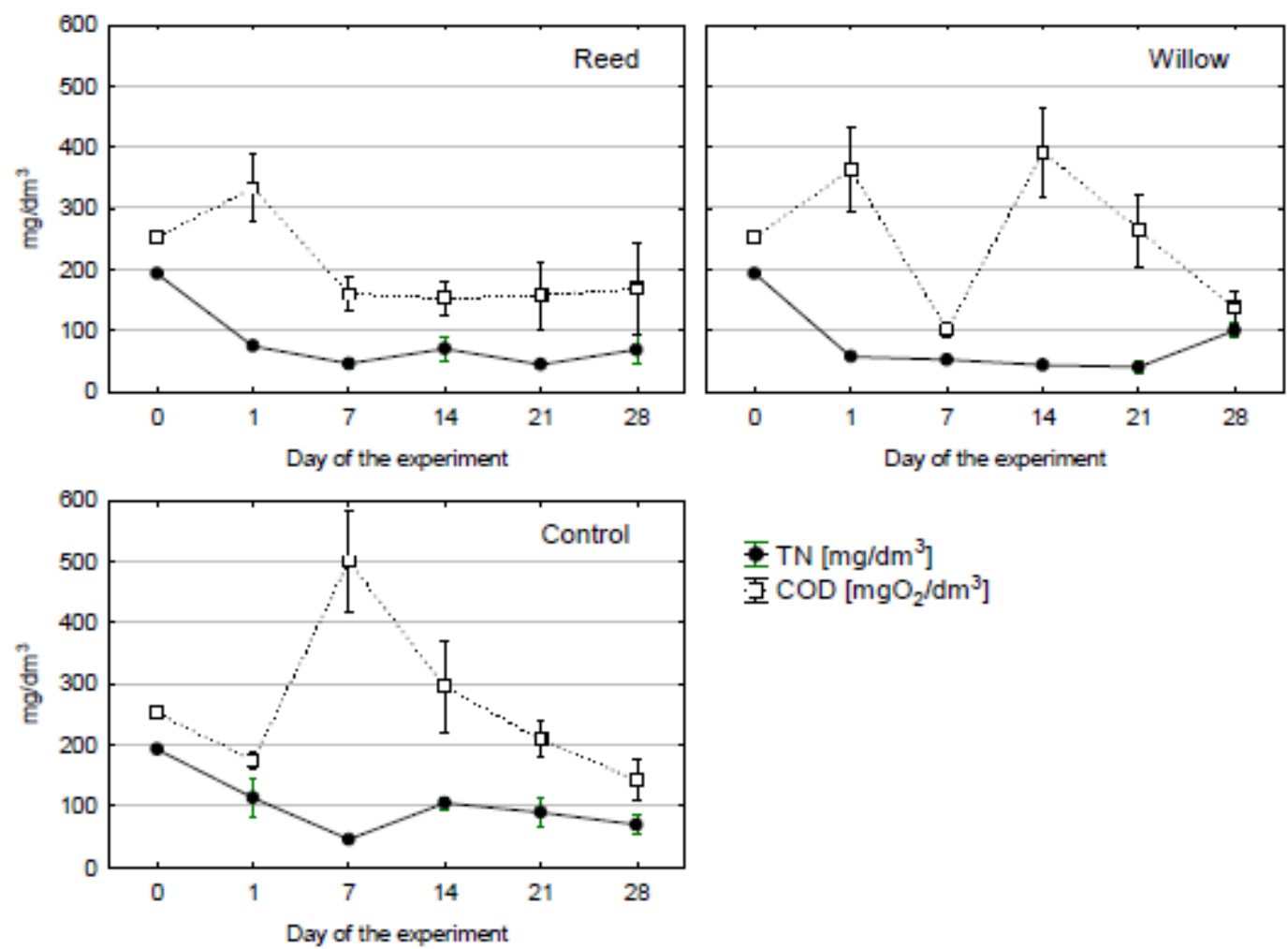

Figure 4. Changes in concentration of total- $N$, and COD in samples of $L L$ (A-reed, Bwillow, C-control)

The temperature in the greenhouse was prevented from falling below $14^{\circ} \mathrm{C}$, which may have affected any relationship between the temperature and Eh, as light intensity also plays a role in the relationship between these two factors and this may have been negated by the artificial heating. Eh values indicated that reed tends to raise Eh above typical [13] anoxic levels by releasing either more oxygen or less organic exudates than willow. These exudates, which make up 5-25\% of photosynthetically fixed carbon, assist denitrification and the degradation of toxic organic chemicals [5, 16]. Willow maintained Eh at anoxic levels but close to anaerobic, what could promote more efficient denitrification, and anaerobic decomposition of organic compounds.

The amount of oxygen in the rhizosphere fluctuates over diurnal periods and varies between seasons. There is higher oxygen release in periods of illumination and even in periods of reasonably low light intensity the amount of oxygen released into the rhizosphere can meet the respiratory oxygen demand of the roots and micro-organisms in the rhizosphere [17]. Fluctuations in Eh were found when measured hourly between 08:00 and 18:00. These fluctuations were most pronounced in the willow tank with a large decrease in Eh in the morning after the sun had risen and a subsequent steady increase. [8] found fluctuations in Eh over diurnal cycles in wetlands containing Phragmites australis with Eh decreasing in light and increasing in dark periods. The decrease in Eh during light hours was attributed to the ability of plants to transport oxygen and the release of plant-root exudates into the rhizosphere, which served as a substrate for heterotrophic microorganisms resulting in increased microbial activity and utilisation of oxygen, thus decreasing Eh. It would appear that species differences affect the fluctuations of Eh in the rhizosphere during diurnal cycles, as there was a marked 
difference in the fluctuations between the reed and willow tanks, with the reed tank having only slightly more variation in Eh than the control tank.

[23] found diurnal cycling of oxygen levels in willow rhizospheres were affected by weather and day/night changes. The decrease in Eh in the willow tank in the morning could be attributed to the release of photosynthetic exudates into the rhizosphere after the sun rose and the subsequent increase in Eh could be attributed to the later release of oxygen into the rhizosphere.

\subsection{Landfill leachate treatment}

Ammonium was removed successfully from the LL in all tanks, with the willow tank being the most efficient having the lowest levels after the first week. Interestingly, the decline in $\mathrm{NH}_{4}^{+}$in the willow tank was not followed by a rise in $\mathrm{NO}_{2}^{-}$or $\mathrm{NO}_{3}^{-}$, which would be expected if nitrification had taken place. It may be that full or partial nitrification and full denitrification occurred simultaneously and quickly during the first week of the experiment. Plant uptake is another possibility for the removal of the $\mathrm{NH}_{4}{ }^{+}$ in the willow tank. [1] found a combination of plant uptake and nitrification in LL treatment wetlands containing willow resulted in an almost complete removal of $\mathrm{NH}_{4}{ }^{+}$, with nearly half of the $\mathrm{N}$ removed stored in the wetland system, principally in plant tissues as organic $\mathrm{N}$.

In the reed tank there was a peak in $\mathrm{NO}_{2}{ }^{-}$suggesting that nitritation occurred, but there was no rise in concentration of $\mathrm{NO}_{3}{ }^{-}$which would be expected with the removal of $\mathrm{NO}_{2}{ }^{-}$ through nitratation [13]. It could be that nitrification of $\mathrm{NO}_{2}{ }^{-}$to $\mathrm{NO}_{3}{ }^{-}$and subsequent denitrification of the $\mathrm{NO}_{3}{ }^{-}$took place, but that due to the relatively long time period between sampling the changes in the concentration of the $\mathrm{NO}_{3}{ }^{-}$were not detected. Organic carbon is one of the primary regulators of denitrification of $\mathrm{NO}_{3}{ }^{-}$[15] and both the reeds and the LL itself may have provided an organic carbon source for the denitrification process. Another possible reason for the lack of $\mathrm{NO}_{3}{ }^{-}$in the reed tank could be plant uptake, as it has previously been found that in rhizospheres with low $\mathrm{N}$ availability competition between plant uptake and microbial use of $\mathrm{NO}_{3}{ }^{-}$can limit denitrification [10]. A further potential pathway for $\mathrm{NO}_{2}^{-}$removal, which does not involve denitrification to $\mathrm{NO}_{3}{ }^{-}$, is direct denitrification of $\mathrm{NO}_{2}^{-}$to $\mathrm{N}_{2} \mathrm{O}$ and $\mathrm{N}_{2}$ [9]. However, this only occurs under conditions of oxygen stress [20].

In the control tank the decline in $\mathrm{NH}_{4}{ }^{+}$with the subsequent peak and decline in $\mathrm{NO}_{2}{ }^{-}$ and later peak in $\mathrm{NO}_{3}{ }^{-}$suggests that nitrification of $\mathrm{NH}_{4}{ }^{+}$and $\mathrm{NO}_{2}{ }^{-}$took place. The slight decline in $\mathrm{NO}_{3}{ }^{-}$after week three suggests that some denitrification took place in the control tank. However, levels remained high compared to the reed and willow tanks, which could have been due to a lack of organic carbon needed for further denitrification to take place [15], and the absence of plant uptake.

\section{CONCLUSIONS}

Plants control the redox potential by oxygen and release of organic compounds into the root zone. Reed tends to maintain typical anoxic conditions, but willow regulates Eh 
close to anaerobic. Control tank Eh was controlled only by oxygen diffusion from the surface, and decomposition of dead biofilm. These different patterns of performance showed differences in pathways of nitrogen removal between variants.

Reeds and willows positively affect the treatment of LL as there are lower $\mathrm{TN}, \mathrm{NO}_{3}{ }^{-}$, and COD concentrations in tanks containing these plants than an unplanted control. This is probably achieved through plant uptake and the effects of enhanced levels of oxygen and organic carbon in the rhizosphere on nitrification and denitrification.

\section{ACKNOWLEDGEMENTS}

This experimental work was done with financial support of the fellowship of Dr Andrzej Białowiec held at Cardiff University, School of Biosciences, granted by Polish Ministry of Science and Higher Education No. 219/MOB/2008/0. Data analysis was carried out with financial support of EVAWET project - PTDC/AMB/73081/2006.

\section{REFERENCES}

[1] Alker, G.R., Godley, A.R., Hallett, J.E., 2003. Landfill Leachate Management by Application to Short Rotation Willow Coppice. In. Proceedings of Ninth International Waste Management and Landfill Symposium S. Margherita di Pula, Cagliari, Italy; 6 10 October 2003 by CISA, Environmental Sanitary Engineering Centre, Italy.

[2] Allen, W.C., Hook, P.B., Biederman, J.A., Stein, O.R., 2002. Temperature and Wetland Plant Species Effects on Wastewater Treatment and Root Zone Oxidation. $J$. Environ. Qual. 31, 1010-1016.

[3] Białowiec, A., Wojnowska-Baryła, I., Agopsowicz, M., 2007. The efficiency of evapotranspiration of landfill leachate in the soil-plant system with willow Salix amygdalina L. Ecol. Eng. 30(4), 356-361.

[4] Bialowiec A., Randerson P., 2010. Phytotoxicity of landfill leachate on willow Salix amygdalina L. Waste Manage. 30, 1587-1593.

[5] Brix, H. 1997. Do macrophytes play a role in constructed treatment wetlands? Water Sci. Technol. 35, 11-17.

[6] Christensen, T.H., Cossu, R., Stegmann, R. 1992. Landfill Leachate: an Introduction. In: Landfilling of Waste: Leachate (Eds. Christensen, T.H., Cossu, R., Stegmann, R.). Elsevier, Barking, UK, pp 1-14.

[7] Duggan, J., 2005. The Potential for Landfill Leachate Treatment Using Willows in the UK: A Critical Review. Resour. Conserv. Recy. 45, 97-113

[8] Dušek, J., Picek, T., Č́źžková, H., 2008. Redox potential dynamics in a horizontal subsurface flow constructed wetland for wastewater treatment: diurnal, seasonal and spatial fluctuations. Ecol. Eng. 34, 223-232.

[9] Faulwetter, J.L., Gagnon, V., Sundberg, C., Chazarenc, F., Burr, M.D., Brisson, J., Camper, A.K., Stein, O.R., 2009. Microbial Processes Influencing Performance of Treatment Wetlands: A Review. Ecol. Eng. 35, 987-1004.

[10] Fromin, N., Tarnawski, S., Roussel-Delif, L., Hamelin, J., Baggs, E.M., Aragno, M., 2005. Nitrogen fertiliser rate affects the frequency of nitrate-dissimilating Pseudomonas spp. in the rhizosphere of Lolium perenne grown under elevated pCO2 (Swiss FACE). Soil Biol. Biochem. 37, 1962-1965.

[11]Jones D.L., Williamson, K.L., Owen, A.G., 2006. Phytoremediation of landfill leachate. Waste Manage. 26, 825-837. 
[12]Kjeldsen, P., Barlaz, M.A., Rooker, A.P., Baun, A., Ledin, A., Christensen, T.H., 2002. Present and Long-Term Composition of MSW Landfill Leachate: a Review. Crit. Rev. Env. Sci. Tec. 32, 297-336.

[13] Randerson, P.F., 2006. Constructed wetlands and vegetation filters: an ecological approach to wastewater treatment. Environmental Biotechnology 2, 78-89.

[14]Reddy, K.R., Patrick, W.H., Lindau, C.W., 1989. Nitrification-denitrification at the Plant-Root Sediment Interface in Wetlands. Limnol. Oceanogr. 34, 1004-1013.

[15] Schipper, L.A., Cooper, A.B., Harfoot, C.G., Dyck, W.J., 1993. Regulators of Denitrification in an Organic Riparian Soil. Soil Biol. Biochem. 25, 925-933.

[16] Schnoor, J.L., Licht, L.A., McCutcheon, S.C., Wolfe, N.L., Carreira, L.H., 1995. Phytoremediation of organic and nutrient contaminants. Environ. Sci. Technol. 29, 318323.

[17] Sheppard, S.K., Lloyd, D., 2002. Diurnal Oscillations in Gas Production $\left(\mathrm{O}_{2}, \mathrm{CO}_{2}\right.$, $\mathrm{CH}_{4}$ and $\mathrm{N}_{2}$ ) in Soil Monoliths. Biol. Rhythm Res. 33, 577-597.

[18] Sorrell, B.K., Armstrong, W., 1994. On the difficulties of measuring oxygen release by root systems of wetland plants. J. Ecol. 82, 177-183.

[19] Stein, O.R., Hook, P.B., 2005. Temperature, plants and oxygen: how does season affect constructed wetlands performance. J. Environ. Sci. Heal. 40, 1331-1342.

[20] Stevens, R.J., Laughlin, R.J., Malone, J.P., 1998. Soil pH affects the processes reducing nitrate to nitrous oxide and di-nitrogen. Soil Biol. Biochem. 30, 1191-1126.

[21] Welander, U., Henrysson, T., Welander, T., 1998. Biological nitrogen removal from municipal landfill leachate in a pilot scale suspended carrier biofilm Process. Water Res. 32, 1564-1570

[22] Wießner, A., Kuschk, P., Stottmeister, U., 2002 Oxygen release by roots of Typha latifolia and Juncus effusus in laboratory hydroponic systems. Acta Biotechnol. 22, 209216.

[23] Williams H.G., Białowiec A., Slater F., Randerson P.F., 2010 Diurnal cycling of dissolved gas concentrations in a willow vegetation filter treating landfill leachate. Ecol. Eng. (in press).

[24] Wojciechowska E., Obarska-Pempkowiak H., 2008. Performance of reed beds supplied with municipal landfill leachate. In: Wastewater Treatment, Plant Dynamics and Management in Constructed and Natural Wetlands, Ed. Vymazal J., Springer, Netherlands, pp. 251-265.

[25] Wojciechowska E., Gajewska M., Waara S., Obarska-Pempkowiak H., Kowalik A., Albuquerque A., Randerson P., 2009. Leachate from sanitary landfills treated by constructed wetland. In. Proceedings of $12^{\text {th }}$ International Waste Management and Landfill Symposium, S. Margherita di Pula (Cagliari), Sardinia, Italy, 5-9 Oct 2009, pp. $1-12$. 